Abstract AB0781 - Table 1. Characteristics of 16 patients with Scleroderma renal crisis

\begin{tabular}{|c|c|c|c|c|c|c|c|c|c|c|c|c|c|}
\hline \multicolumn{3}{|c|}{ Pt.No Age(y) Sex } & \multirow{2}{*}{$\begin{array}{c}\begin{array}{c}\text { SRC } \\
\text { duration(y) }\end{array} \\
0.25\end{array}$} & \multirow{2}{*}{ 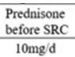 } & \multirow{2}{*}{$\begin{array}{l}\text { SSc } \\
\text { form } \\
\text { deSSc }\end{array}$} & \multirow{2}{*}{$\begin{array}{l}\text { Pulmonary } \\
\text { fibrosis } \\
+\end{array}$} & \multirow{2}{*}{$\begin{array}{c}\begin{array}{c}\text { Cardiac } \\
\text { involvement }\end{array} \\
+\end{array}$} & \multirow{2}{*}{\multicolumn{2}{|c|}{ PAH MAHA }} & \multirow{2}{*}{$\begin{array}{c}\begin{array}{c}\mathrm{BP} \\
(\mathrm{mm} H \mathrm{H})\end{array} \\
170 / 100\end{array}$} & \multirow{2}{*}{$\begin{array}{c}\begin{array}{c}\text { Ser } \\
(\text { (umolL })\end{array} \\
2066\end{array}$} & \multirow{2}{*}{$\begin{array}{c}\text { ACE inhibitor } \\
\text { None }\end{array}$} & \multirow{2}{*}{$\begin{array}{c}\text { Outcome } \\
\text { Recovered }\end{array}$} \\
\hline 1 & 62 & $\mathrm{~F}$ & & & & & & & & & & & \\
\hline 2 & 20 & $\mathrm{~F}$ & 10 & None & & & + & + & + & & & Irbesartan & \\
\hline 3 & 61 & $\mathrm{~F}$ & 1 & $30 \mathrm{mg} / \mathrm{d}$ & desse & + & & + & & $170 / 100$ & 153 & Lotensin & Recovered \\
\hline 4 & 60 & M & 1 & 30mgd & dcSSc & & & & & $175 / 128$ & s11 & Captopril & $\mathrm{CKD}$ \\
\hline 5 & 65 & M & 5 & None & desse & + & + & & & 19897 & 174 & Captopril & Recovered \\
\hline 6 & 64 & $\mathrm{M}$ & 5 & & desse & + & & + & + & 19090 & 504 & Captopril & CKD \\
\hline & 62 & $\mathrm{~F}$ & 1 & & & 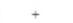 & + & + & + & $130 / 102$ & 420 & Cappopril & died \\
\hline 8 & 64 & $\mathrm{~F}$ & 10 & & & + & + & + & & $160 / 110$ & 259 & & \\
\hline 9 & 58 & M & 2 & 15 & $\mathrm{dc}$ & + & + & & & $189 / 122$ & 49 & Captopril & Recovered \\
\hline 10 & 24 & $\mathrm{M}$ & 0.5 & 30 & deSSc & + & + & & + & 200 & 86 & pril & Dialysis \\
\hline 11 & 64 & M & 8 & & csSc & + & & & + & $194 / 102$ & 400 & Cap & CKD \\
\hline & & $\mathrm{F}$ & 15 & & deSsc & + & + & & + & $200 / 120$ & 248 & Captopril & died \\
\hline 13 & 61 & M & 2 & 15mgd & deSsc & & & & & 11070 & 969 & Captopril & Dialysis \\
\hline 14 & 61 & F & 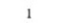 & $15 \mathrm{mgd}$ & lessc & & + & & & $193 / 110$ & 587 & & CKD \\
\hline 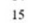 & 58 & 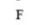 & 1 & & & + & 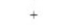 & & & & 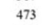 & & \\
\hline 16 & 46 & & 3 & & $\begin{array}{l}\text { desSe } \\
\text { dest }\end{array}$ & 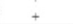 & + & & & $80 / 100$ & 992 & aptopril & died \\
\hline
\end{tabular}

SRC: Scleroderma renal crisis, SSc: systemic sclerosis, dcSSc: diffuse cutaneous SSc, IcSSc: limited cutaneous SSc, PAH: pulmonary arterial hypertension, MAHA: microangiopathic haemolytic anaemia, CKD: chronic kidney disease Conclusions: Medium-to-high doses of glucocorticoids (prednisone $\geq 7.5 \mathrm{mg} / \mathrm{d}$ ) were associated with an increased risk of SRC. Cardiac involvement was common and associated with high mortality in SRC patients.

Disclosure of Interest: None declared

DOI: 10.1136/annrheumdis-2018-eular.6559

\section{AB0782 SYSTEMIC SCLEROSIS PATIENTS WITH CONCOMITANT PSORIASIS: A PROOF-OF-CONCEPT PILOT STUDY}

L. Magnani ${ }^{1}$, G. Bajocchi ${ }^{1}$, I. Chiarolanza ${ }^{1}$, A. CAruso ${ }^{1}$, R. Aldigeri ${ }^{2}$, C. Salvarani ${ }^{1}$. ${ }^{1}$ ASMN Reggio Emilia, Reggio Emilia; ${ }^{2}$ Università di Parma, PARMA, Italy

Background: Psoriasis and Systemic Sclerosis (SSc) are chronic inflammatory diseases characterised by a systemic immunological response which is mainly driven by activated T helper (Th) Th1/Th17 lymphocytes.. ${ }^{1,2}$ Further, genomewide association studies (GWAS) in SSc have demonstrated an association at PSORS1C1, the same gene linked to psoriasis susceptibility ${ }^{3}$

Objectives: Evaluate the statistical significance of a clinical correlation between Scleroderma and Psoriasis

Methods: From April 2014 to April 2017, we enrolled 180 consecutive patients with a diagnosis of ${ }^{S S c}$ fullililing $2013 \mathrm{ACR} / \mathrm{EULAR}$ classification criteria. Patients with Localised Scleroderma (Morphea) had to have a diagnostic skin biopsy before being included. Patients satisfying VEDOSS criteria ${ }^{4}$ were also included. Patients with psoriasis had a dermatologist-prooven diagnosis.

Results: $11 / 180$ (6.1\%\%, 95\% IC:0.03-2.9) with scleroderma had a dermatologist-proven diagnosis of Psoriasis, and 23 patients (12.7\%) had a family history of Psoriasis in a first-degree relative. For all the psoriatic patients except one, BMI was calculated; $50 \%$ had a BMI of $>20$ (average: 23.7 ). A metabolic syndrome was present in 3 out of $11(27.2 \%)$, and in ten patients there were data available to calculate the presence of average moderate cardiovascular (CV) risk $(11.5 \%)$. Finally, $3 / 11$ patients $(27.2 \%)$ had Psoriatic Arthritis (CASPAR classification criteria). In all 11 patients, Psoriasis was defined as mild (PASI $\leq 10) .{ }^{5}$ The average value of modified Rodnan Skin Score (mRSS) was curiously low (0.5), [limited cutaneous (IcSSc) 5 patients, Morphea 3 patients, Very Early Systemic Sclerosis (VEDOSS) 2 patients, and diffuse cutaneous disease (dcSSc) 1 patient. Anticentromere antibodies (ACA) were detected in 5/11 patients; antinuclear antibodies, with negative extractable nuclear antigens in 4/11; Anti-topoisomerase I were found in two cases.

Conclusions: Psoriasis was significantly associated with SSc $(p=0.014)$, with a 2 -fold higher frequency than that observed in general population (3\%). Psoriasis $+\mathrm{SSc}$, represent a further increased risk of CV disease. Th17 seems to play a crucial role in the pathogenesis of both diseases.

\section{REFERENCES:}

[1] Fava A, Cimbro R, Wigley FM, et Al. Frequency of circulating topoisomerase-I specific CD4 T cells predicts presence and progression of interstitial lung disease in scleroderma Frequency of circulating topoisomerase-I specific CD4 T cells predicts presence and progression of interstitial lung disease in scleroderma. Arthritis Research \& Therapy 2016; (18)99:1-12.

[2] Lei L, Zhao C, Qin F, He Z-Y, Wang X, et al. Th17 cells and IL-17 promote the skin and lung inflammation and fibrosis process in a bleomycininduced murine model of systemic sclerosis. Clin Exp Rheumatol 2016; 34 (S 100): S14-S22.

[3] Allanore Y, Saad M, Dieude P, et al. Genome-Wide Scan Identifies TNIP1, PSORS1C1, and RHOB As Novel Risk Loci for Systemic Sclerosis. PLoS Genetics 2011; (7)7: 1-13.

[4] Minier T, Guiducci S, Bellando-Randone S Preliminary analysis of the very early diagnosis of systemic sclerosis (VEDOSS) EUSTAR multicentre study: evidence for puffy fingers as a pivotal sign for suspicion of systemic sclerosis. Ann Rheum Dis 2014;73(12):2087-93.
[5] Marks R, Barton SP, Shuttleworth D, Finlay AY. Assessment of disease progress in psoriasis. Arch Dermatol 1989;125:235-40.

Disclosure of Interest: None declared

DOI: 10.1136/annrheumdis-2018-eular.3745

\section{AB0783 CLINICAL CHARACTERISTICS OF A COHORT OF PATIENTS WITH ANTI-JO1 ANTIBODIES}

M.C. Carrasco Cubero ${ }^{1}$, S.M. Rojas Herrera ${ }^{2}$, M.L. Vargas Pérez ${ }^{3}$, M.I. Alcalá Peña ${ }^{3}$ M. Espárrago Rodilla ${ }^{4}$, E. Chamizo Carmona ${ }^{2} .{ }^{1}$ Rheumatology, CHU Infanta Cristina; ${ }^{2}$ Rheumatology, Hospital de Mérida; ${ }^{3}$ Immunology, CHU Infanta Cristina; ${ }^{4}$ Immunology, Hospital de Mérida, Badajoz, Spain

Background: Anti-synthetase syndrome (ASSD) is characterised by myositis associated with anti-synthetase antibodies, fever, arthritis, Raynaud's phenomenon, "mechanic's hands" and diffuse interstitial lung disease (ILD); $80 \%$ of patients present incomplete forms. The most frequently detected anti-synthetase antibody is anti-Jo1 (anti-histidyl-tRNA synthetase), which usually leads to a greater lung involvement. In some cases of myositis, the simultaneous presence of anti-Jo1 and anti-Ro52 antibodies has been described, and it is debated whether the presence of both antibodies is accompanied by more severe pulmonary involvement.

Objectives: To compare the clinical manifestations of the positive anti-Jo1 patients, with and without associated anti-Ro52 antibodies.

Methods: This is a retrospective observational study of anti-Jo1 positive patients confirmed in the Immunology Laboratory, between 2009 and 2018. Two techniques were used to identify the anti-Jo1 and anti-Ro52 antibodies: Western blot (EUROLINE Myositis Profile 3 ( $(\mathrm{gG})$ ) and Fluoroenzimoimmunoassay (EliA, Thermofisher).

Results: In this study, 22 patients with anti-Jo1 antibodies were included, 16 $(72.7 \%)$ women and $6(27.2 \%)$ males. There was no association with FR or ACPA. The mean age was 57.3 years (SD:14.6) and the mean time of follow-up was 4.01 years (SD: 2.1). Of all patients, 5 had ASSD, the rest expressed the clinical picture of incomplete form. The most frequently clinical manifestations associated with anti-Jo1 were: muscular involvement ( $n=18,81.8 \%)$, ILD ( $n=13,59.1 \%)$, arthritis $(n=9,400.9 \%)$, Raynaud's phenomenon $(n=4,18.2 \%)$. No patient developed lesions of mechanic's hands. The majority of patients with muscular involvement $(83.3 \%)$, had histological confirmation of inflammatory idiopathic myopathy (Dermato or Polymyositis). The most frequently found X-ray pattern (HRCT) in patients with ILD was Non-specific interstitial pneumonia (NSIP) $(n=9,69.2 \%)$, followed by 2 Respiratory bronchiolitis interstitial lung disease (RB-ILD) and 2 Idiopathic interstitial pneumonia (IIP). Nine patients presented ILD and Myositis concomitantly $(40.9 \%)$, more than half had fibrosing pulmonary involvement. $50 \%$ $(n=11)$ also had criteria for other autoimmune diseases (2 rheumatoid arthritis, 4 polymiositis, 4 dermatomyositis, and 1 overlap). Half of the patients with anti-Jo1 presented also anti-Ro52, which $27.3 \%$ exclusively developed myopathy, $18.2 \%$ ILD and both entities $54.5 \%$. Half of the ILD presented a radiological fibrosing radiological pattern. During follow-up, 7 patients (31.8\%) died, 2 of metastatic cancer (one renal and one ovarian) and 5 of complications of the ILD, of which $80 \%$ were anti-Jo1/anti-Ro52 "doublet" positives.

Abstract AB0783 - Table 1

\begin{tabular}{lcccccccc}
\hline & $\begin{array}{c}\text { Age } \\
\text { years } \\
\text { (SD) }\end{array}$ & $\begin{array}{c}\text { Follow- } \\
\text { up } \\
\text { years } \\
\text { (SD) }\end{array}$ & $\begin{array}{c}\text { Arthritis } \\
\mathrm{n}(\%)\end{array}$ & $\begin{array}{c}\text { Raynaud } \\
\mathrm{n}(\%)\end{array}$ & $\begin{array}{c}\text { Myositis } \\
\mathrm{n}(\%)\end{array}$ & $\begin{array}{c}\text { ILD } \mathrm{n} \\
(\%)\end{array}$ & $\begin{array}{c}\text { ILD/ } \\
\text { Myositis } \\
\mathrm{n}(\%)\end{array}$ & $\begin{array}{c}\text { Exitus } \\
\mathrm{n}(\%)\end{array}$ \\
\hline Anti-Jo1 & 57,3 & 4,0 & $9(40,9)$ & $4(18,2)$ & $18\left(^{81,8}\right.$ & $13\left({ }^{59,1}\right.$ & $9(40,9)$ & 7 \\
$(\mathrm{n}=22)$ & $(14,6)$ & $(2,1)$ & & & & & & $(31,8)$ \\
"Doublet" & 59,2 & 3,8 & $6(54,5)$ & $3(27,3)$ & $9(81,8)$ & 8 & $6(54,5)$ & 4 \\
Anti-Jo1/ & $(15,3)$ & $(2,0)$ & & & & $(72,7)$ & & $(36,4)$ \\
$\begin{array}{l}\text { Anti-Ro52 } \\
(\mathrm{n}=11)\end{array}$ & & & & & & & & \\
\hline
\end{tabular}

Conclusions: The ILD is a frequent manifestation and the main cause of death in the patients with anti-Jo1 of our cohort. The presence of anti-Jo1/anti-Ro52 "doublet" seems to lead to a worse prognosis in these patients.

Disclosure of Interest: None declared

DOI: 10.1136/annrheumdis-2018-eular.3958 